\title{
The use of woody species in northern Benin
}

\section{Robert Sieglstetter, Karen Hahn \& Rüdiger Wittig}

Summary: The use of woody species of rural populations in Northern Benin was investigated by semi-structured and open interviews. Of the 129 woody species found in the area, $124(96 \%)$ were mentioned to be used as firewood, for house and furniture construction or preparation of tools, for alimentation, in traditional medicine and/or for other purposes. Our study confirms and underlines the high importance of non timber forest products (NTFPs) for the local population

Keywords: Atakora, Ditamari, ethnobotany, firewood, forest products, traditional medicine, pharmacy, savannah, Sudanian zone, Wama

\section{L'UTILISATION DES ESPÈCES LIGNEUSES AU NORD DU BENIN}

Résumé: L'utilisation des espèces ligneuses par les populations rurales du Nord Benin a été étudiée, moyennant des interviews semi-structurés et ouverts. Parmi les 129 espèces qui ont été trouvées dans la région, 124 (96\%) ont été mentionnées comme utilisées, comme bois de chauffe, pour la construction de maisons ou meubles, pour la fabrication d'outils, pour l'alimentation, dans la médecine traditionelle et/ou pour une autre cause. Notre étude confirme et souligne la grande importance des produits forestiers non ligneux (PFNL) pour les populations locales.

Mots clés: Atakora, Ditamari, bois de chauffe, ethnobotanique, produits forestieres, médicine traditionelle, pharmacie, savannah, zone Soudanienne, Wama

\section{Die Nutzung von Gehölzen in Nord-Benin}

Zusammenfassung: Mit halbstrukturierten und offenen Interviews wurde die Nutzung von Gehölzpflanzen in Nord-Benin untersucht. Von den 129 Gehölzen, die im Gebiet gefunden wurden, werden 124 (96\%) genutzt als Feuerholz, für die Konstruktion von Häusern, Möbeln oder Werkzeugen, für die Ernährung, für die traditionelle Medizin und/ oder andere Zwecke. Unsere Untersuchung unterstreicht damit die große Bedeutung von Gehölzpflanzen für die einheimische Bevölkerung.

Schlagworte: Atakora, Ditamari, Brennholz, Ethnobotanik, Holznutzung, traditionelle Medizin, Pharmazie, Savanne, Sudanzone, Wama

\section{INTRODUCTION}

Human survival and well-being are highly dependent on nature e.g., CostanZA \& DALY, 1992; Costanza et al., 1997; MYERS \& REICHERT, 1997). Although this statement is true for all regions of the world, it is particularly relevant in the rural population of the so-called developing countries. In these regions, the relationships between people and nature are much more direct than in industrialised countries. The first step towards an understanding of these close relationships and dependencies is the documentation of the services obtained from nature. Accordingly, this paper presents an overview on the use of woody species by the local population in the Atakora region of Benin.

\section{Area of InVEstigation}

Our study area (Fig. 1) was located in northern Benin (in the department of Atakora), which phytogeographically belongs to the southern Sudanian zone. This zone is characterised by the annual alternation of the dry and wet seasons. The wet season extends from May through November (annual rainfall ca. $1,300 \mathrm{~mm} / \mathrm{m}^{2}$ ). The mean annual temperature is 27 ${ }^{\circ} \mathrm{C}$. The vegetation is primarily the result of the prevailing type of agriculture, i.e., of shifting cultivation. After several years of tillage, the cleared fields lie fallow for 6 to 15 years. This practice creates a mosaic of recent and fallow crop fields that resembles a savannah landscape. According to STURM (1994), deciduous dry forests represent the potential natural vegetation of the area.
Within the Atakora department, we selected three villages, Kounadorgou, Péperkou and Tipéti, for our investigation. The dominant ethnic group in Kounadorgou and Tipéti is the Ditamari (or Bétamaribé), whereas Péperkou is a village of the Wama.

\section{Methods}

During 2000 and 2001, randomly but group-specifically (see below), questionnaires were administered in interviews with selected inhabitants of the three villages. The collection of fuel wood is a task for women. The use of wood for the construction of houses, furniture and tools is a male area of expertise. Therefore, in view of this differentiation in expertise, only the members of the expert group were considered in each case. Equal percentages of men and women were interviewed regarding the use of woody plants for medicinal purposes. In addition, we conducted semi-structured and open interviews (MARTIN 1995, SCHNELL et al. 1988).

One year before beginning the survey, the first author of this paper spent three months in the area and visited all of the villages several times to gain the trust of the people. In the years during which the interviews were conducted, he lived in one of the villages from January through March. Furthermore, to ensure the accuracy of the species names provided by the interviewees, the local names of the species were documented and cross-checked (CUNNINGHAM 2001). 
The keys and descriptions of BRUNEL et al. (1984), GEERLING (1982) and HuTCHINSON et al. (1954) were used for species determinations. The results of these analyses were confirmed in the Herbaria of the Senckenberg Museum, Frankfurt, and the Botanical Museum, Dahlem, Berlin. The herbarium specimens were deposited at FR.

\section{Results}

Of the 130 woody species found in the area, 124 (Table 1) were mentioned by the interviewees as sources of firewood, as materials for the construction of houses and furniture or the preparation of tools, as food sources, and/or as plants used in traditional medicine. In all, 43 species are used as firewood. However, they are not all equally appreciated. 17 of these species are considered to be of good quality. Of these species, seven are used to produce charcoal. For construction and other "technical" applications (including the preparation of spoons), 30 species are preferentially used. Parts (primarily the fruits or seeds, more rarely the leaves, very rarely the roots and in one case the flowers: Table 1) of 41 species are eaten or applied as spices. A pharmaceutical use was cited for 71 species. Eleven species are used for magi- cal ceremonies, seven for magical ceremonies, four as packaging materials and one as colouring matter.

\section{Discussion AND Conclusions}

Our study confirms and underscores the great importance of forest products (NTPs) to local populations in Africa. This significance was also documented by others (CAVENDISH 2002, KRISTENSEN \& BALSLEV 2003, LYKKE et al. 2004, SCHUMANN et al. 2010, BundSCHUH et al. 2011). HeUBACH et al. (2011) showed that NTFPs contributed substantially to the income of two other villages in the Atakora region. However, due to climate and land use changes impacting West African savannahs (HAHN-HADJALI \& THIOMBIANO 2000, IPCC 2007, SALA et al. 2000, WiTTIG et al. 2007), the availability and sustainable use of these ecosystem services are endangered. The security of the rural livelihoods dependent on these services is likewise threatened. We hope that our striking documentation of the high importance of the use of woody species will help to prevent the West African savannah from complete conversion to an impoverished landscape dominated by agro-industrial use.

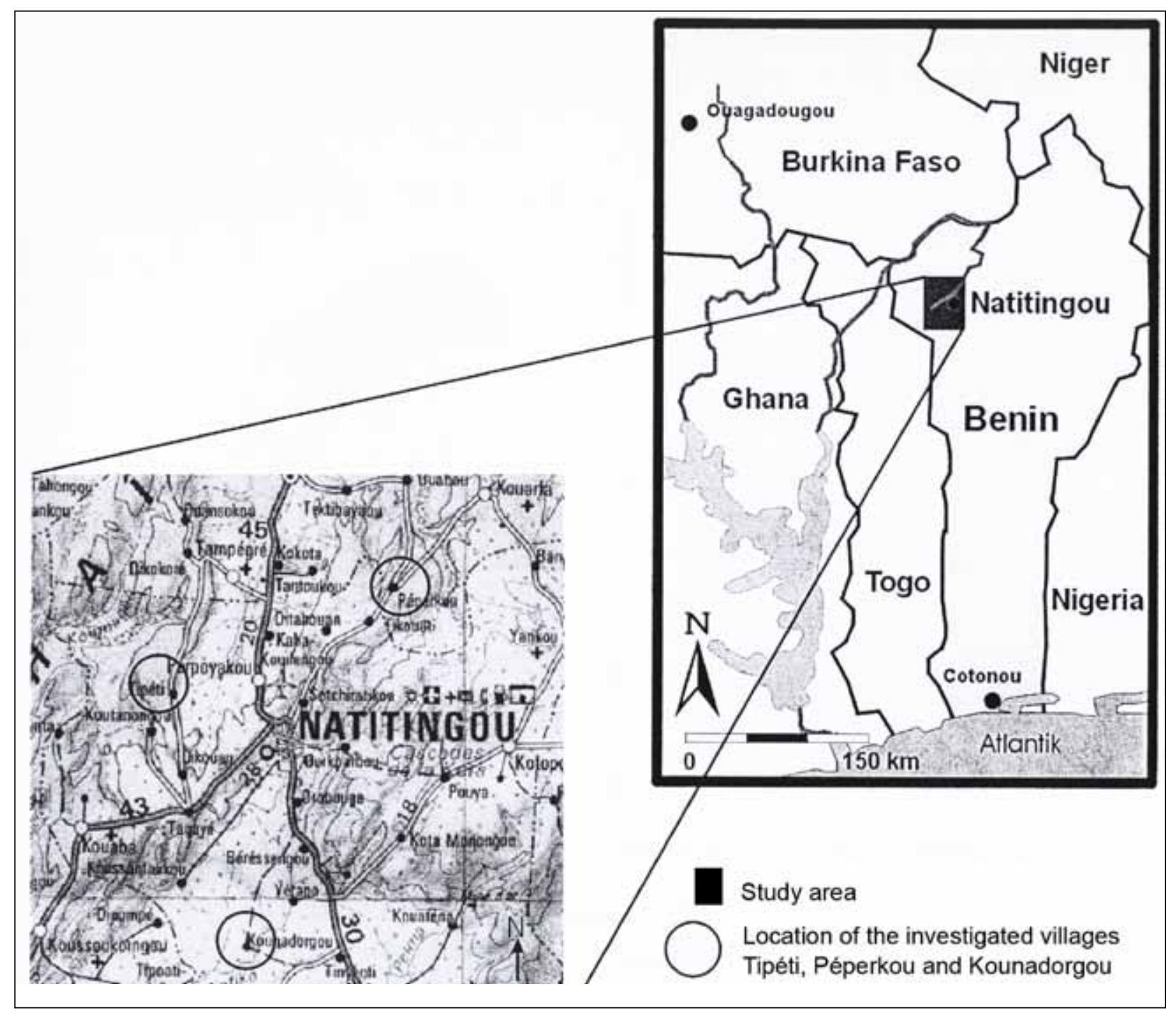

Fig. 1: Study area and location of the investigated villages/ Zone d'étude et position des villages investigés/ Untersuchungsgebiet und Lage der untersuchten Dörfer 
Table / Tableau / Tabelle 1: The use of woody species / l'utilisation des especes lingneuxes / die Nutzung von Holzpflanzen

\begin{tabular}{|c|c|c|c|c|c|c|c|}
\hline Species & Fw & $L \& T$ & Aliment. & $\mathbf{P h}$ & H & Magic & Other \\
\hline Acacia dudgeonii & & + & & & & & Z \\
\hline Acacia hockii & & + & & & & & 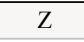 \\
\hline Adansonia digitata & & & $\mathrm{L}, \mathrm{S}, \mathrm{F}$ & + & & & \\
\hline Afzelia africana & & & & + & & + & I \\
\hline Albizia zygia & 0 & & & + & & & \\
\hline Allophyllus cobbe & & & & & + & & \\
\hline Anacardium occidentale & 0 & & $\mathrm{~F}, \mathrm{~S}$ & & & & \\
\hline Annona senegalensis & & & $\mathrm{F}, \mathrm{L}$ & + & & + & \\
\hline Anogeissus leiocarpa & & + & $\mathrm{F}$ & & & & \\
\hline Anthocleista nobilis & & & & + & & & \\
\hline Azadirachta indica & & & & + & & & \\
\hline Baissea multiflora c.f. & & & $\mathrm{L}$ & & & & \\
\hline Balanites aegyptiaca & & & & + & & & \\
\hline Bambusa vulgaris & & + & & & & & \\
\hline Berlinia grandiflora & & + & $\mathrm{L}$ & & & & \\
\hline Blighia sapida & & & F & + & + & & \\
\hline Bombax costatum & & & $\mathrm{B}$ & + & & & \\
\hline Borassus aethiopium & & & $\mathrm{S}$ & + & & + & $\mathrm{M}$ \\
\hline Breonadia salicina & & & & & + & & \\
\hline Bridelia ferruginea & & + & $\mathrm{F}$ & & & & \\
\hline Bridelia scleroneura & & & $\mathrm{F}$ & & & & \\
\hline Burkea africana &,$+ \mathrm{C}$ & + & & & & & \\
\hline Byrsocarpus coccineus & & & & + & & & \\
\hline Canthium multiflorum & & & & & & & $\mathrm{C}$ \\
\hline Canthium venosum & & + & & & & & $\mathrm{F}$ \\
\hline Cassia sieberiana & & + & & + & & & \\
\hline Ceiba pentandra & & & & + & & & \\
\hline Citrus spec. & & & $\mathrm{F}$ & + & & & \\
\hline Clematis hirsuta & & & & + & & & \\
\hline Cochlospermum tinctorium & & & $\mathrm{R}$ & & & & \\
\hline Combretum collinum & + & & & & + & & \\
\hline Combretum fragrans & 0 & & & + & & & \\
\hline Combretum molle & & + & & + & & & \\
\hline \multicolumn{8}{|l|}{ Combretum nigricans } \\
\hline Commiphora excelsa & & & & + & & & \\
\hline Crossopteryx febrifuga &,$+ \mathrm{C}$ & + & & + & & & \\
\hline Cussonia barteri & & & & + & & & \\
\hline Daniella oliveri & + & & & + & & & \\
\hline Detarium microcarpum & + & & $\mathrm{F}$ & + & & & \\
\hline Dichrostachys cinerea & 0 & + & & + & & + & $\mathrm{Z}$ \\
\hline Dioscorea dumetorum & & & $\mathrm{R}$ & & & & \\
\hline Dioscorea togoensis & & & $\mathrm{R}$ & & & & \\
\hline Diospyros mespiliformis & & + & $\mathrm{F}$ & & & & \\
\hline Ekebergia senegalensis & 0 & & & & & & \\
\hline Entada africana &,$+ \mathrm{C}$ & & & + & & & \\
\hline Erythrina senegalensis & & & & + & & & \\
\hline Erythrophleum africanum &,$+ \mathrm{C}$ & + & & & & & G \\
\hline Euphorbia unispina & & & & + & & + & \\
\hline Fadogia agrestis & & & $\mathrm{F}$ & + & & & \\
\hline Fadogia erythrophloea & 0 & & & + & & & \\
\hline Ficus capensis & + & & & & & & $\mathrm{F}$ \\
\hline Ficus gnaphalocarpa & & & $\mathrm{F}$ & & & & \\
\hline Garcinia ovalifolia & + & & $\mathrm{F}$ & & + & & \\
\hline Gardenia aqualla & & & & + & & & \\
\hline Gardenia erubescens & 0 & & $\mathrm{~F}$ & + & & + & $\mathrm{Z}$ \\
\hline Gardenia tenuifolia & & & & + & & & \\
\hline Grewia bicolor & 0 & & $\mathrm{~F}$ & & & & \\
\hline Grewia cissoides & & & $\mathrm{F}$ & & & & \\
\hline Grewia mollis & 0 & & $\mathrm{~F}$ & & & & \\
\hline Haematostaphis barteri & & & $\mathrm{F}$ & + & & & \\
\hline Hexalobus monopetalus & 0 & + & $\mathrm{F}$ & & & & $\mathrm{R}$ \\
\hline Hymenocardia acida & 0 & + & $\mathrm{L}, \mathrm{S}, \mathrm{F}$ & + & & & \\
\hline
\end{tabular}




\begin{tabular}{|c|c|c|c|c|c|c|c|}
\hline Species & Fw & $\mathbf{L} \& \mathbf{T}$ & Aliment. & $\mathbf{P h}$ & $\mathbf{H}$ & Magic & Other \\
\hline Isoberlinia doca & + & + & & + & & & $\mathrm{P}$ \\
\hline Isoberlinia tomentosa & 0 & + & & & & & $\mathrm{P}$ \\
\hline Khaya senegalensis & 0 & + & & + & & & \\
\hline Lannea acida & 0 & & $\mathrm{~F}$ & + & & & \\
\hline Lannea microcarpa & & & $\mathrm{F}$ & & & & \\
\hline Lophira lanceolata & & + & $\mathrm{S}$ & + & & & \\
\hline Mangifera indica & & & F & + & & & \\
\hline Manilkara multinervis & 0 & + & & & + & & \\
\hline Margaritaria discoidea & 0 & & & & & & \\
\hline Maytenus senegalensis & & & & + & & & \\
\hline Monotes kerstingii & + & + & & + & & & \\
\hline Nauclea latifolia & & & $\mathrm{F}$ & + & & & \\
\hline Ochna schweinfurthiana & & & & + & & & \\
\hline \multicolumn{8}{|l|}{ Oncoba spinosa } \\
\hline Opilia celtidifolia & & & & + & & & \\
\hline Oxytenanthera abyssinica & & + & & + & & & \\
\hline Ozoroa insignis & & & & & & & $\mathrm{S}$ \\
\hline Parinari curatellifolia & 0 & & & + & & & \\
\hline Parkia biglobosa & 0 & & $\mathrm{~F}$ & & & & \\
\hline Paullinia pinnata & & & $\mathrm{F}$ & + & & & \\
\hline Pavetta crassipes & & & & + & & & \\
\hline Pentadesma butyracea & + & + & $\mathrm{S}$ & & & & \\
\hline Pericopsis laxiflora &,$+ \mathrm{C}$ & + & & + & & & \\
\hline Phyllanthus muellerianus & 0 & & $\mathrm{~F}$ & + & & & \\
\hline Piliostigma thonningii & & & & + & & & $\mathrm{P}, \mathrm{R}$ \\
\hline Prosopis africana & & & & + & + & & \\
\hline Protea madensis & & & & + & & & \\
\hline Pseudocedrela kotschii & 0 & & & & & & \\
\hline Psorospermum senegalense & & & & + & + & & \\
\hline Pteleopsis suberosa & & + & & + & & & $\mathrm{R}$ \\
\hline Pterocarpus erinaceus &,$+ \mathrm{C}$ & + & & + & & & \\
\hline Pterocarpus santalinoides & & & $\mathrm{F}$ & & & & \\
\hline Quassia undulata & & + & & & & & \\
\hline Rhaphia sudanica & & + & $\mathrm{S}$ & & & + & \\
\hline Sclerocayia birrea & & & F & & & & \\
\hline Securidaca longepedunculata & & & & + & & & \\
\hline Securinega virosa & & & & & & + & M,I \\
\hline Smilax kraussiana & & & & + & & & \\
\hline Steganotaenia araliacea & & & & + & + & & \\
\hline Sterculia setigera & & & $\mathrm{S}$ & + & + & & \\
\hline Stereospermum kuntianum & & & & + & & & \\
\hline Strophanthus sarmentosus & & & & + & & & $\mathrm{G}$ \\
\hline Strychnos innocua & & & & & & + & \\
\hline Strychnos spinosa & & & $\mathrm{F}$ & + & & & I \\
\hline Swartzia madagascariensis & 0 & + & & & & & \\
\hline Syzygium guineense & 0 & & & + & & & \\
\hline Tamarindus indica & & & $\mathrm{F}$ & + & & & \\
\hline Tapinanthus bangwensis & & & & & & + & \\
\hline Tapinanthus dodoneifolius & & & & & & + & \\
\hline Terminalia avicennioides & 0 & & & & & & \\
\hline Terminalia glaucescens & + & + & & + & + & & \\
\hline Terminalia laxiflora & 0 & & & & & & \\
\hline Tricalysia chevalieri & & & & + & & & \\
\hline Trichilia emetica & & & & + & & & \\
\hline Uapaca togoensis &,$+ \mathrm{C}$ & & & + & & & $\mathrm{P}$ \\
\hline Vitellaria paradoxa & 0 & & $\mathrm{~S}$ & + & + & & \\
\hline Vitex doniana & & & $\mathrm{F}$ & & & & \\
\hline Vitex simplicifolia & 0 & & $\mathrm{~F}$ & & & & \\
\hline Ximenia americana & & & $\mathrm{R}$ & + & & & \\
\hline Zanha golungensis & + & & & & & & \\
\hline Zanthoxylum zanthoxyloides & & & $\mathrm{R}$ & + & & & \\
\hline Ziziphus mucronata & & & & + & & & \\
\hline
\end{tabular}

Fw Firewood: + preferred, 0 also used, C Charcoal production,

L\&T Lumber and tools

Aliment. Alimentation: B Flowers, F Fruits, L Leaves, R Roots, S Seeds

Ph Pharmacy, traditional medicine
H Hygiene

Magic used in magical ceremonies

Others: C Coloration, F Fishing, G Poison, I Musical Instruments, M Mats, P Packaging Material, R Ropes, S Spears, Z Fencing 


\section{ACKNOWLEDGEMENTS}

This study was financed by the Deutsche Forschungsgemeinschaft (DFG) within the framework of the Collaborative Research Center 268 (Sonderforschungsbereich 268). For technical support, we are indebted to Prof. Dr. Brice Sinsin, the current rector of the University of Abomey-Ca-

\section{REFERENCES}

BRUNEL JF, HiePKo P \& SCHOLZ H (1984): Flore analytique du Togo - Phanerogames. GTZ, Berlin, Eschborn.

BundSChUH TV, HAHN K \& WitTIG R (2011): The Medicinal Plants of the Woodlands in Northern Malawi (Karonga District).- Flora Veg. Sudano-Sambesica 14: 3-9.

CAVENDISH W (2002): Quantitative methods for estimating the economic value of resource use to rural households. Uncovering the Hidden Harvest: Valuation Methods for Woodland and Forest Resources. Earthscan publications Ltd., London.Costanza and Daly, 1992.

Costanza R, D’Arge R, De Groot R, Farber S, Grasso M, Hannon B, Limburg K, NaEem S, Oneill RV, Paruelo J, Raskin RG, SutTon P \& VAN DEN Belt M (1997): The value of the world's ecosystem services and natural capital. Nature 387: 253-260.

GeERLING C (1982): Guide de terrain des lignieux saheliens et soudano-guineens. Veenman \& Zoonen, Wageningen.

Hahn-Hadjali K \& ThiombianoA. (2000): Perception des espèces en voie de disparition en milieu gourmantché (Es du Burkina Faso). Berichte des Sonderforschungsbereich 68: $285-297$

Heubach K, Wittig R \& Nuppenau E-A \& Hahn, K. (2011): The economic importance of non-timber forest products (NTFPs) for livelihood maintenance of rural west African communities: A case study from northern Benin. Ecol. Econom.; doi:10.1016/j.ecolecon.2011.05.015

HutCHINSON J, DALZIEL JN \& KEAY RWJ (1954): Flora of West Tropical Africa. Millbank, London.

IPCC (2007): Climate Change 2007: The Physical Science basis. Contribution of Working Group I to the Fourth Assessment Report of the Intergovernmental Panel on Climate Change, Cambridge.

Kristensen M \& Balslev H (2003): Perceptions, use and availability of woody plants among the Gourounsi in Burkina Faso. Biodiversity and Conservation 12: 17151739.

LYKKE AM, KRISTENSEN MK \& GANABA S (2004): Valuation of local use and dynamics of 56 woody species in the Sahel. Biodiversity and Conservation 13(10): 19611990. lavi. In addition, the first author wishes to thank the inhabitants of the studied villages for their hospitality and also wishes to thank Kouaga N'Tcha Borinati, who was an excellent guide and interpreter.

Myers JP \& ReICHERT JS (1997): Perspectives on Nature's Services, in: Daily, G.C. (Ed.), Nature's Services: Societal Dependence on Natural Ecosystems. Island Press, Washington, D.C.

Sala OE, Chapin III FSC, Armesto JJ, Berlow E, Bloomfield J, Dirzo R, Huber-Sanwald E, HuenNeKe LF, JACKSON RB, Kinzig A, LeEmans R, Lodge DM, Mooney HA, Oesterheld M, Poff NL, Sykes MT, WALKER BH, WALKER M \& WALL D (2000): Global Biodiversity Scenarios for the Year 2100. Science 287: 1770-1774.

Schumann K, Wittig R, Thiombiano A, Becker U \& HAHN K (2010): Impact of land-use type and barkand leaf-harvesting on population structure and fruit production of the baobab tree (Adansonia digitata L.) in a semi-arid savanna, West Africa. Forest Ecology and Management 260: 2035-2044.

WitTIG R, KÖNIG K, SCHMIDT M \& SZARZYNSKI J (2007): A study of climate change and anthropogenic impacts in West Africa. Environmental Science and Pollution Research 14: 182-189.

\section{ADDRESSES OF THE AUTHORS}

\section{Dr. Robert Sieglstetter \\ Dr. Karen Hahn* \\ Prof. Dr. Rüdiger Wittig*}

Institute of Ecology, Evolution and Diversity

Goethe-Universität

Max-von-Laue-Str. 13

D-60438 Frankfurt am Main, Germany

* and: Biodiversity and Climate Research Centre

(BiK-F)

D-60325 Frankfurt am Main, Germany

eMail: r.wittig@bio.uni-frankfurt.de eMail: karen.hahn@bio.uni-frankfurt.de 